\author{
Arkadiusz Stajszczak¹, Bożena Wujec², Iwona Ksiądzyna ${ }^{3}$ \\ Akademia Leona Koźmińskiego w Warszawie \\ ${ }^{1}$ Katedra Marketingu \\ e-mail: a.stajszczak@wp.pl \\ ${ }^{2}$ Centrum Coachingu \\ e-mail: bozena.wujec@inspired.pl \\ ${ }^{3}$ Centrum Coachingu \\ e-mail: iwona.ksiadzyna@gmail.com
}

\title{
Trust in effective relationship management on the procurement market
}

JEL code: L14

Keywords: trust, business relations, experience with the product, business needs, emotional needs

\begin{abstract}
The aim of this article is to present the results of research concerning farmers' trust in the manufacturers of crop protection chemicals. The authors examined farmers' level of trust in the three groups of manufacturing companies: innovative companies, generic companies, and hybrid companies. The results show that the highest level of trust in the crop protection chemicals market is ascribed to the innovative companies. This high level of confidence is influenced, above all, by previous positive experience of the farmers with the product or manufacturer, the scale of the marketing activities of such companies, the number of their products available on the market, and the on-site customer support regarding decision making during shopping.
\end{abstract}

\section{Introduction}

The aim of this article is to present the results of research concerning farmers' trust in the manufacturers of crop protection chemicals. The authors examined farmers' level of trust in the three groups of manufacturing companies: innovative companies, generic companies, and hybrid companies. 
During the research that was conducted from November to December 2015, there were surveys carried out with the CATI technique on the sample of 1,019 farmers. The target group were farms with a surface area above 15 ha. The applied sampling method was quota sampling, with the sampling distribution consistent with the GUS 2013 data, and it covered 205-271 farms.

Trust as a business phenomenon, despite the fact that recently it has been carefully analysed, still cannot find its place in the research literature regarding crop protection chemicals. This market has crucial, from the research point of view, characteristic conditioning. A farmer makes a decision whether to purchase a product or not on the basis of his/her previous positive experience related to the application of the product (Stajszczak, 2011b, pp. 472-481).

The results of the research conducted show that the highest level of trust on the crop protection chemicals market is ascribed to the innovative companies. This high level of trust is influenced, above all, by previous positive experience of the farmers with the product or manufacturer, the scale of the marketing activities of such companies, the number of their products available on the market, and the onsite customer support regarding decision making during shopping.

The size of this article does not allow for the elaboration on all of the aspects concerning this topic. Thus the authors concentrate on the selected and important subjects. They include: the influence of trust on the relationships, experience concerning the product, and the degree of satisfying business and emotional needs by the trading partners.

\section{Trust as a vital factor in business relations}

For a few years, trust has been lying in the centre of interest of the researchers who analyse business relationship management. Table 1 presents a review of the most crucial definitions of the concept of trust.

Table 1

Selected definitions of the term 'trust'

\begin{tabular}{|l|l|}
\hline $\begin{array}{l}\text { A belief that the other party's word is reliable or credible } \\
\text { (honesty) }\end{array}$ & Buttle, Maklan (2015) \\
\hline $\begin{array}{l}\text { A belief that the other party has the necessary expertise to } \\
\text { perform as required (competence) }\end{array}$ & Buttle, Maklan (2015) \\
\hline $\begin{array}{l}\text { Trust is a bet in which the subject is the uncertain, future } \\
\text { actions of other people }\end{array}$ & Sztompka (2007) \\
\hline $\begin{array}{l}\text { Trust is the expectation on the other party's capability, } \\
\text { goodwill, and self-reference, which needs to be confirmed by } \\
\text { experience }\end{array}$ & Blomqvist, Staehle (2004) \\
\hline
\end{tabular}




\begin{tabular}{|l|l|}
\hline $\begin{array}{l}\text { Expectation held by an agent that its trade partner would } \\
\text { Behave in a mutually acceptable manner }\end{array}$ & Sako, Helper (1998) \\
\hline $\begin{array}{l}\text { Trust is a mechanism by which actors reduce the internal } \\
\text { complexity of their system of interaction through the adoption } \\
\text { of specific expectations about the future behaviour of the other } \\
\text { by selecting amongst a range of possibilities }\end{array}$ & Luhmann (1979) \\
\hline
\end{tabular}

Source: authors on the basis of: Grudzewski, Hejduk, Sankowska, Wańtuchowicz, 2009.

A characteristic feature, common for these selected definitions, is the fact that trust is prior to the transaction, it consists of a conviction about the reliability of the other party before the actual confirmation of such credibility takes place through the application of a product. The authors of these definitions point to the phenomena accompanying trust, such as: honesty, credibility, and goodwill.

Trust is especially important on the markets where the quality of the product can only be verified after a long time since its purchase, and, at the moment of making a decision, a client does not have a perfect knowledge of this product (Forlicz, 2001). In such conditions, the client forms his/her purchase preferences on the basis of previous experience with a salesperson or a manufacturer, or he/she develops an idea concerning this product on the basis of the incomplete information that is available, for example packaging or a name that is easy to remember (Wanat, 2010).

Such markets involve mostly procurement markets, for example agricultural supply stores. This market has essential, from the research point of view, characteristic conditioning that regards farmers' purchase decisions (Stajszczak, 2015). Farmers rarely make their purchase decisions without taking into account the appearance and visual attributes of a product. They do this mostly on the basis of previous positive experience with a product or a manufacturer, or on the basis of a belief that this product will function as expected. In this very case, trust is a bet that concerns the future effectiveness of the product. On such a market, these are the qualities of a relationship - trust level and shared values - that decide about the success (Stajszczak, 2012).

Figure 1 presents the scheme of establishing relationships on a B2B market on the basis of trust, which later develop into relationships based on positive business and emotional experience. By experience, one should understand interactions related to business transactions (products, special offers, channel for reaching a customer, sales efforts, and price/quality level), and actions in the emotional sphere. Such an experience, once it is positive, leads to contentment and satisfaction with fulfilled needs. Satisfaction with the relationship is fundamental in building loyalty understood as readiness for negotiations and openness to exchange arguments. The thing that combines all the next steps is communication (Tarabasz, 2007). 


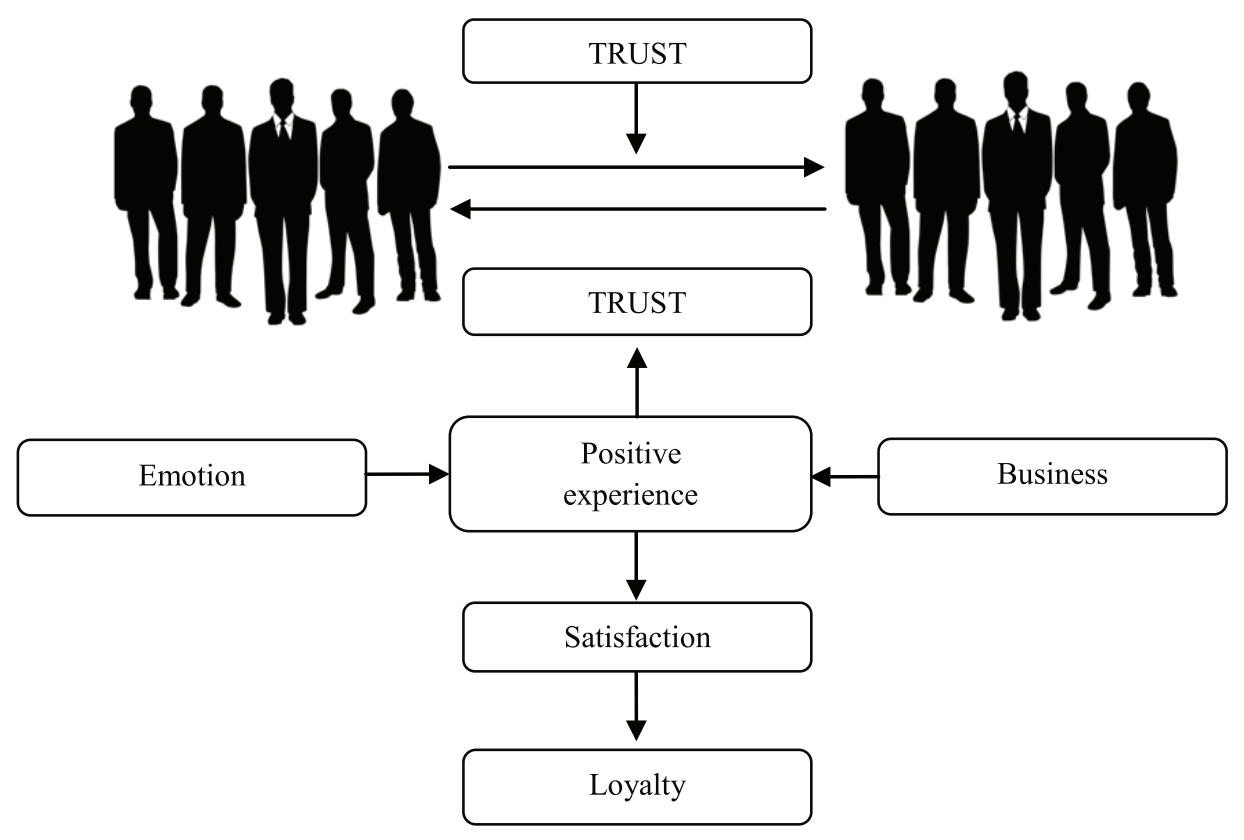

Figure 1. Trust in establishing relationships on a B2B market

Source: own elaboration.

On the market connected to crop protection chemicals, there are three groups of manufacturing companies, namely: innovative companies, generic companies, and hybrid companies. Innovative companies, also known as research and development companies, are the ones which meet new needs or the old ones, but through the application of a new active substance (biologically active), new formula, or new application method. They bring a new and unknown aspect to the agricultural practice. Generally, they are subject to patent protection. Generic companies are the ones which have not developed, discovered, or patented any active substances, and their products do not have any licence or any other exclusive rights, however, they do have the same biologically active substance as the original products, but it is derived from another source. Moreover, their chemical composition is the same or very similar to the original one (similar processing aids and solvents), and they can be interchangeable with the original (innovative) products. Hybrid companies offer a range of products that are a combination of generic and innovative products. The proportion of these products is different depending on the company.

From the marketing viewpoint, both research and development companies and generic companies offer the same basic product and the same primary benefit. They fulfil the same need at the level of a physical product (functional), but they 
address different motivations and values. Besides, they realise different psychophysical characteristics (symbolic) of the product. Figure 2 illustrates the 'means-end' model by Antonides (Antonides, Van Raaij, 2003, p. 160), which presents the significance of functional and symbolic characteristics in the product realisation of the values.

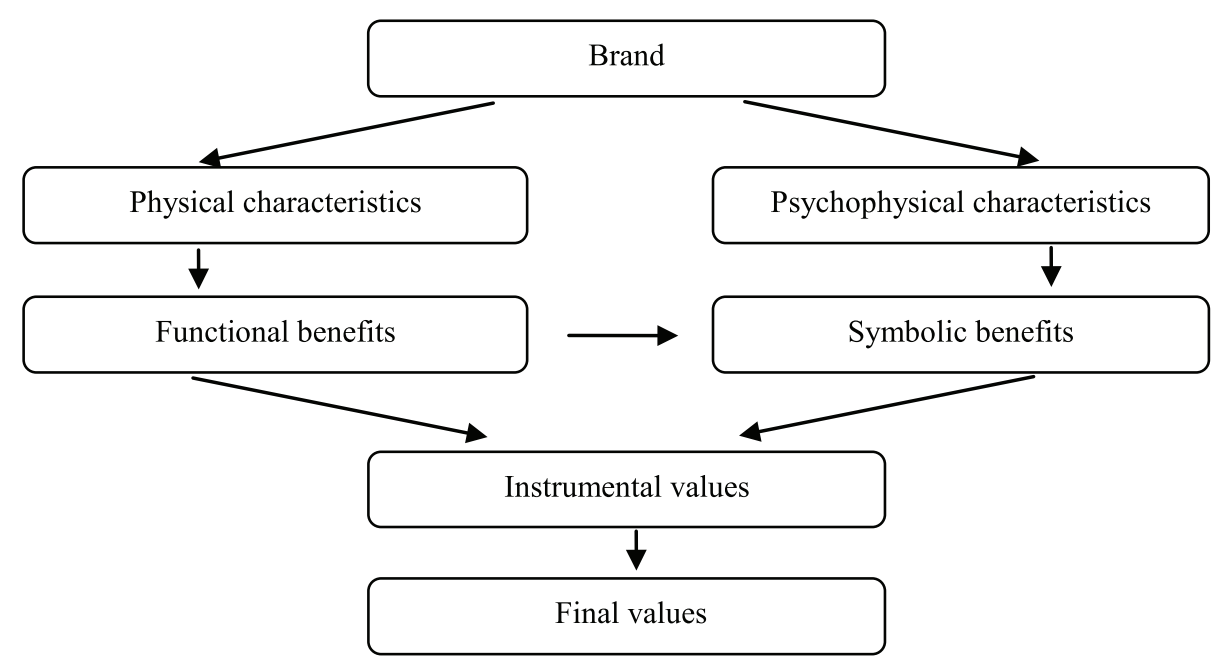

Figure 2. The concept of physical (functional) and psychosocial (symbolic) characteristics of the product in realisation of the values for the customer

Source: Antonides, Van Raaij, 2003, p. 160.

By means of the analysis of the product characteristics that are desired by the customers on the crop protection chemicals market, one can conclude that customers expect greater effectiveness, greater speed, and broader scope of activity from the innovative products. On the other hand, generic products are expected to be cheaper. Original products provide a greater sense of security while generic products give the sense of maximising savings (Stajszczak, 2011a).

Once trust is taken into account, it turns out that through choosing a group from which products will be purchased, a farmer has to calculate his/her trust. $\mathrm{He} /$ she makes a choice whether to stay with the more expensive original product or take a risk and buy the much cheaper product, which has never been used before by the individual. 


\section{Testing method}

The presented study is a part of a research project run by the authors, that deals with building a relationship on the crop protection chemicals market. The authors were interested in how farmers' trust in various groups of crop protection chemicals is built.

The subject of the research was farmers' trust in the manufacturers of crop protection chemicals and their previous experience with the application of the products of these manufacturers. The companies on the market were divided into three groups: innovative (incl. Bayer, BASF, Syngenta), generic (incl. Cheminova, Helm, Sarzyna) and hybrid - the companies that offer both types of products (incl. Adama, Arysta, Belchim). These companies form three discrete strategic groups that employ different product and pricing strategies, as well as the strategies concerning customer relationship management.

Farmers and the employees of agricultural supply warehouse were surveyed. These surveys were carried out from November to December 2015 on the sample of 1,019 farmers. They were conducted with the CATI technique (computer-supported interviews held on farms). The target group were the farms with a surface area above $15 \mathrm{ha}$. The researchers are interested in the opinions of the farmers operating on such areas ( 15 ha is the threshold of commercial farms), and those exceeding 50 ha as a minimal size of developmental farms.

The applied sampling method was quota sampling (area of voivodeship) with the sampling distribution consistent with the GUS 2013 data, and it covered 205-271 farms.

\section{Research results}

The results of the research are presented in Table 2.

Table 2

Assessment of the level of trust depending on the membership of the strategic group (\%)

\begin{tabular}{|l|c|c|c|c|c|c|}
\hline \multicolumn{1}{|c|}{$\begin{array}{c}\text { Company } \\
\text { group }\end{array}$} & $\begin{array}{c}\text { High } \\
\text { level } \\
\text { of trust }\end{array}$ & $\begin{array}{c}\text { Lack } \\
\text { of trust }\end{array}$ & $\begin{array}{c}\text { Previous } \\
\text { positive } \\
\text { experience }\end{array}$ & $\begin{array}{c}\text { Support from the store } \\
\text { and warehouse } \\
\text { employees }\end{array}$ & $\begin{array}{c}\text { Supported } \\
\text { brand } \\
\text { awareness }\end{array}$ & $\begin{array}{c}\text { Market } \\
\text { shares }\end{array}$ \\
\hline $\begin{array}{l}\text { Innovative } \\
\text { companies }\end{array}$ & 62 & 11 & 80 & 26 & 47 & 65 \\
\hline $\begin{array}{l}\text { Hybrid } \\
\text { companies }\end{array}$ & 49 & 15 & 15 & 6 & 25 & 15 \\
\hline $\begin{array}{l}\text { Generic } \\
\text { companies }\end{array}$ & 45 & 16 & 10 & 4 & 22 & 20 \\
\hline
\end{tabular}

Source: own elaboration. 
The results of the research show that the farmers put their trust in the innovative companies $(62 \%)$ that also have the largest market share $-65 \%$. Only $11 \%$ of the farmers declare the lack of trust in such companies. As far as hybrid companies are concerned, once their market share equals $15 \%$, a high level of trust is declared by $49 \%$ of the farmers. On the other hand, a high level of trust in generic companies (market share equals 20\%) is declared by $45 \%$ of the farmers. $15 \%$ of the farmers declare the lack of trust in hybrid companies, and $16 \%$ of the farmers do not trust generic companies. As many as $80 \%$ of the farmers declare previous positive experience with the products purchased from the innovative companies, whereas experience with the products from hybrid and generic companies is relatively low $-15 \%$ and $10 \%$, respectively. $26 \%$ of the farmers notice the support provided by the store and warehouse employees only in the case of innovative companies. As far as hybrid and generic companies are concerned, such support is declared by $6 \%$ and $4 \%$ of the farmers, respectively. The level of supported brand awareness is also the highest in the case of innovative companies and it amounts to $47 \%$. As far as hybrid and generic companies are concerned, it equals $25 \%$ and $22 \%$ of the farmers, respectively.

\section{Conclusions}

The highest level of trust on the crop protection product market is ascribed to the innovative companies. This high level of trust is influenced, above all, by previous positive experience of the farmers. This is due to the fact that the quality and effectiveness of these chemicals can be identified only after its application (i.e. after some time since the purchase).

The fact that the farmers declared the highest trust in innovative companies (which are on the market for a longer period than the generic and hybrid ones, and which have the highest market share) results from brand awareness (measured here as supported brand awareness), that is the result of marketing activities undertaken by innovative companies and the number of products available on the market.

The support of the store and warehouse employees during shopping is also significant for building trust in the brand, and it is present mainly in the case of innovative companies. It is due to the fact that stores have strong and long-lasting relationships with innovative companies that partially finance these stores' operations.

The results are coherent and indicate the significance of trust during farmers' decision making regarding the purchase of a crop protection product. 


\section{Summary}

The presented results concerning farmers' trust in the three groups of the companies producing crop protection chemicals (innovative companies, generic companies, and hybrid companies) explicitly indicate that the highest level of trust is ascribed to the research and development companies. This high level of confidence is influenced, above all, by previous positive experience of the farmers with the product or manufacturer, the scale of the marketing activities of such companies, the number of their products available on the market, and the support provided by the store employees during farmers' decision making.

For the managers, the above conclusions point at the necessity of developing an attractive range of products and supporting it by means of appropriate marketing activities. Thus the authors realise that there is the need for further research covering the identification of the effectiveness of particular marketing tools that serve building trust.

\section{Bibliography}

Antonides, G., Van Raaij, W.F. (2003). Zachowanie konsumenta. Warszawa: Wydawnictwo Naukowe PWN.

Blomqvist, K., Staehle, P. (2004). Trust in technology partnerships. In: M.L. Houtari, I. Livonen (eds.) Trust in knowledge management and systems in organizations. Hershey, PA: Idea Group Pub.

Buttle, F., Maklan, S. (2015). Customer relationship management: concepts and technologies. London \& New York: Routledge, Taylor \& Francis Group.

Forlicz, S. (2001). Niedoskonała wiedza podmiotów rynkowych. Warszawa: Wydawnictwo Naukowe PWN.

Grudzewski, W.M., Hejduk, I.K., Sankowska, A., Wańtuchowicz, M. (2009). Zarzadzanie zaufaniem w przedsiębiorstwie, koncepcja, narzędzia, zastosowania. Kraków: Wydawnictwo Wolters Kluwer.

Luhmann, N. (1979). Trust and power. Chichester: John Wiley.

Sako, M., Helper, S. (1998). Determinants of trust in supplier relations: Evidence from the automotive industry in Japan and the United States. Journal of Economic Behavior and Organization, 34 (3).

Stajszczak, A. (2011a). Innowacyjność produktów a satysfakcja klientów. In: K. Świerszcz, J. Śliwa (eds.), Innowacje przedsiębiorstw a satysfakcja klientów w teorii i praktyce. Warszawa: Wydawnictwo Społecznej Wyższej Szkoły Przedsiębiorczości i Zarządzania w Łodzi. 
Stajszczak, A. (2011b). Zachowania nabywcze a komunikacja marketingowa na rynku środków ochrony roślin. In: B. Pilarczyk (ed.), Komunikacja marketingowa, strategie i instrumenty. Zeszyty Naukowe Uniwersytetu Ekonomicznego w Poznaniu, 208, 472-481.

Stajszczak, A. (2012). Innowacje czy imitacje? Oryginały czy generyki? Zachowania nabywcze rolników na rynku środków ochrony roślin. Handel Wewnętrzny, 1.

Stajszczak, A. (2015). Znaczenie ceny jako punktu odniesienia w kształtowaniu preferencji nabywczych. Handel Wewnętrzny, 1 (354), 252-260.

Sztompka, P. (2007). Zaufanie. Fundament społeczeństwa. Kraków: Wydawnictwo Znak. Tarabasz, A. (2007). Komunikacja jako kluczowy instrument budowania relacji. In: O. Witczak (ed.) Budowanie zwiazków z klientami na rynku business to business. Warszawa: Wydawnictwa fachowe CeDeWu.pl.

Wanat, T.M. (2010). Atrybuty produktu a konstruowanie preferencji przez nabywców. Poznań: Wydawnictwo Uniwersytetu Ekonomicznego.

\section{Zaufanie w skutecznym zarządzaniu relacjami na rynku zaopatrzeniowym}

Słowa kluczowe: zaufanie, relacje biznesowe, doświadczenie produktu, potrzeby biznesowe, potrzeby emocjonalne

Streszczenie. Celem artykułu jest zaprezentowanie wyników badań na temat zaufania rolników do producentów środków ochrony roślin. Autorzy zbadali poziom zaufania rolników do trzech grup firm producenckich: firm innowacyjnych, generykowych i hybrydowych. Wyniki badań pokazują, że najwyższym poziomem zaufania na rynku produktów ochrony roślin cieszą się firmy innowacyjne. Na ten wysoki poziom zaufania wpływają przede wszystkim: wcześniejsze pozytywne doświadczenia rolników z produktem lub producentem, skala działań marketingowych firm innowacyjnych, liczba ich produktów dostępnych na rynku oraz wsparcie ze strony sklepów przy podejmowaniu decyzji rolników o zakupie produktu.

\section{Citation}

Stajszczak, A., Wujec, B., Ksiądzyna, I. (2016). Trust in effective relationship management on the procurement market. Marketing i Zarzadzanie, 5 (46), 77-85. 